\title{
DISCLOSURE OF STRATEGIC RESOURCES: IS A COMPETITIVE ADVANTAGE OF COMPANIES OF STOCK EXCHANGE THE \\ BRAZILIAN?
}

Ruan Carlos dos Santos Faculdade São Luiz; Uniasselvi; Unilas; Unicesumar, Brazil E-mail: ruan_santos1984@hotmail.com

Thais Helena Moreira Pinho Faculdade Luciano Feijão-FLF; Centro Social Clodoveu Arruda CSCA, Brazil E-mail: thaismoreiracontabilidade@hotmail.com

Submission: 2/14/2019

Revision: 3/20/2019

Accept: $3 / 28 / 2019$

\section{ABSTRACT}

The understanding of competitive advantages is one of the major theoretical questions in strategy research. It is known that strategic resources generate competitive advantage and that the disclosure of strategic information in a transparent way, mainly of resources, values the organization for investors and works as an attraction. Within this context, it was analyzed whether the dissemination of strategic resources influences the performance of organizations. Twenty companies from the São Paulo Stock Exchange of the most profitable sector of B3 from 2010 to 2018 were part of the analysis. A qualitative approach is adopted through a detailed analysis of the strategic resources of the Reference Forms. This analysis was carried out with the aid of Atlas TI software. After this step the number of disclosure of strategic resources was compared with the performance measured by ROE. The study contributes to the evolution of strategy research in relation to RBV and Theory of Disclosure and, as a practical contribution, to assist in the strategic choice of disclosed information. It was concluded that the disclosure of strategic resources does not influence the performance of the sample companies. 
INDEPENDENT JOURNAL OF MANAGEMENT \& PRODUCTION (IJM\&P)

http://Www.ijmp.jor.br

V. 10, n. 6, November-December 2019

ISSN: 2236-269X

DOI: 10.14807/ijmp.v10i6.1008

Companies choose to disclose what is advantageous and do not consider it advantageous to disclose strategic resources because there is a greater risk of competitors copying their strategy of resources.

Keywords: Competitive Advantage; RBV; Disclosure of information; Performance

\section{INTRODUCTION}

Competitive advantage can be considered the achievement of superior results above the average of the competitors as a result of the strategies adopted by the organization (VASCONCELOS; CYRINO, 2000). Carvalho, Kayo and Martin (2010) affirm that the term competitive advantage, although it is used in the economy as well as in strategy and administration in general, does not present a clear definition, although there is an area of intersection between value creation and superior performance of companies.

Given the above, the greatest challenge for managers is to maintain competitive advantage in a turbulent and highly competitive market in which strategies can contribute to advances for a short period of time, but in order to overcome this challenge, executives and researchers seek to understand the causes that lead certain companies to be more competitive than the others and obtain better results (OYADOMARI et al., 2009).

Penrose (2009) sought to explain the company's growth and the role of resources in this progress, as the company assumes an economic role by acquiring and organizing resources in a cost-effective way. Beuren and Marcello (2016) consider strategic resources essential for an organization to gain competitive advantage.

One of the difficulties in identifying and evaluating the resources of an organization is the lack of quality of the management information systems when presenting resources separately and incompletely. One example is the Balance Sheet when it highlights resources inefficiently and underestimates and capacities (GRANT, 1991).

In order to ensure better use of information, companies should follow the guidelines of Garllon and Beuren (2009): to provide information that allows stakeholders, managers and investors to understand and evaluate the company's activities through qualitative and quantitative data. 
INDEPENDENT JOURNAL OF MANAGEMENT \& PRODUCTION (IJM\&P)

http://Www.ijmp.jor.br

v. 10, n. 6, November - December 2019

ISSN: 2236-269X

DOI: 10.14807/ijmp.v10i6.1008

The disclosure of strategic information values organizations in the capital market. For this reason, it relies on the Theory of Disclosure for dealing with the disclosure of accounting data (BEUREN; ANGONESE, 2015) from various expectations. In order to add to the strategy research, the idea developed in this study is to analyze how the disclosure of organizational resources influences the performance of the sample companies by means of the detailed analysis of their Reference Forms. In order to obtain a satisfactory and useful result for other organizations, the strategy was generally approached, the RBV with an emphasis on the resources studied by Barney and the Theory of Disclosure by Verrecchia (1983) and Dye (1985).

Based on Serra's studies, Ferreira, Pereira and Lissoni (2017) analyzed the last 10 years of articles published in EnANPAD (Meeting of the National Association of Graduate Studies and Research in Administration), highlighting some points in relation to the evolution of a strategy study with a RBV approach in Brazil and propose an agenda that can guide future research.

They note a tendency for case studies, more empirical than purely theoretical. They are part of the theoretical research agenda associated with RBV, core competency, dynamic capabilities, knowledge management and RBV relation with other theoretical approaches. The present work intends to fill the last research gap recommended by these authors.

In view of this context, the question that directs the present research whose objective is to satisfy the following question is formulated: The disclosure of strategic organizational resources influences the performance of the companies of the most profitable sector listed in B3 in the two years of greatest performance between 2010 to 2018 Brazil has been negotiating large amounts of resources in other countries and, in order to demonstrate its attractiveness, the number of financial disclosures, responsibilities and ethical behavior of the companies (FORTE; SANTOS-NETO; NOBRE; DE-QUEIROZ, 2016) has increased in this way the Brazilian capital market is recognized worldwide as one of the most important and presented a great evolution in the volume of shares traded in Brazil, from $1.21 \%$ of Gross Domestic Product (GDP) in 1990 to $43.15 \%$ in 2010 , fourth place in the world in market value (ARANHA et al., 2016). In this way, companies, mainly publicly-held companies, offer the largest possible information, with content referring to current and future businesses (ANGONESE et al., 2014). Still, B3 has encouraged the strengthening of good 
INDEPENDENT JOURNAL OF MANAGEMENT \& PRODUCTION (IJM\&P)

http://Www.ijmp.jor.br

v. 10, n. 6, November - December 2019

ISSN: 2236-269X

DOI: 10.14807/ijmp.v10i6.1008

practices, providing useful and predictive information, by increasing transparency and good corporate governance practices (DONÁ et al., 2015).

The theoretical contributions of this work are aimed at the evolution of strategy research from the viewpoint of the RBV, considering the theoretical framework that best clarifies the superior sustainable performance of companies (BARNEY, 1995; SALAZAR, 2015) for better use of the Theory of Disclosure (VERRECCHIA, 1983; DYE, 1985) and the achievement of a growing organizational performance.

The practical contributions directly focus on the performance of organizations, which seek incessantly better results and are made up of resources, but need to disclose them strategically with quality to be identified and evaluated, with the aim of increasing performance, as well as contributing to business practice in the choice of information to be disclosed.

Therefore, Aragon and Cavalcante (2014) show the importance of the behavior of Brazilian companies in relation to completing the Reference Form, analyze the quality of information and practices in the conduct of business and verify compliance with the requirements of Instruction Comissão de Valores Mobiliários (ICVM) n. 480/2009.

\section{LITERATURE REVISION}

\subsection{Strategy}

Building a strategy means choosing a particular course of action, based on information and data conferencing on the threats and opportunities of the organizational environment (MACHADO-DA-SILVA et al., 1999). Developing strategies is fundamental for any organization (BESANKO et al., 2009). Several of the theoretical approaches that deal with strategy include Penrose (1959), Porter (1980), Dierickx and Cool (1989), Barney (1991), Grant (1991), Peteraf (1993), Collis and Montgomery (1995), Mintzberg (2000), each with its vision in an attempt to innovate and improve business performance, since the depth of strategic knowledge is as important as its size (BESANKO et al., 2009).

Hoskirson et. al. (1999) questions whether strategic management has reverted to its origins as a pendulum swing. It analyzes the main theories, strategic management issues and methods used in each phase and divides the study of the strategy into five moments: early development aimed at the internal vision of the company; oscillation towards the economy of industrial organization as early 
INDEPENDENT JOURNAL OF MANAGEMENT \& PRODUCTION (IJM\&P)

http://www.ijmp.jor.br

v. 10, n. 6, November - December 2019

ISSN: 2236-269X

DOI: 10.14807/ijmp.v10i6.1008

intermediate theories; oscillation back to the company: organizational economics as intermediate theories; back to the starting point, the resource-based view - RBV as current theories. This study discusses the future directions of this constantly evolving research theme, challenged by technological and global dynamics to meet the needs of executives. Finally, it concludes that the oscillations deepen the domain of the strategic area and its evolution is a consequence for the next centuries.

For this reason, strategy studies aim to identify how organizations achieve and maintain competitive advantages (TEECE et al., 1997). Coff (1999) raises the question about competitive advantage does not mean superior performance, the expression is linked to the creation of value, which differentiates it from superior performance. For organizations, strategy is the combination of internal resources, skills, opportunities and risks created by the external environment (GRANT, 1991).

While the majority of the application of strategy theories aims at factors external to the organization, the RBV initially aims at internal factors, trying to understand how the assets are attracted, absorbed, associated and used or provided to the organizational environment. Comparing the idea of Porter (1999), which understands the organization in the field of competitive strategy as a package or set of activities, the RBV understands as a set of exclusive resources (SPANO; LIOUKAS, 2001). For Barney (1991) one of the best ways to create an organizational strategy, whose objective is the achievement of competitive advantage, is to know the internal resources of the company to better use them, scenario proposed by the RBV.

\subsection{RBV - Resource-Based Theory}

One of the most important theoretical currents of the studies developed in strategy is the RBV, because it is adapted to several situations in which the main resources and key factors are determinant for the performance of an organization (CARVALHO et al, 2012). Its origin comes from the studies in strategy, whose initial mark is the research realized by Penrose (1959), with the idea that the limit of the growth of the company is better related with the internal resources than with the market, and the way these resources are used is the singularity of the company (RIBEIRO et al, 2011).

Barney (1991) classifies internal resources into four categories: physical resources, financial resources, human resources, and organizational resources. In the understanding of Oyadomari et al. (2009), internal resources encompass assets, 
INDEPENDENT JOURNAL OF MANAGEMENT \& PRODUCTION (IJM\&P)

http://Www.ijmp.jor.br

v. 10, n. 6, November-December 2019

ISSN: 2236-269X

DOI: 10.14807/ijmp.v10i6.1008

capacities, information, knowledge and processes that contribute positively to organizational efficiency and effectiveness.

Most of the methods of sustaining competitive advantage in the RBV approach have their origin in four key conditions described by Peter (1993): a) heterogeneity: different resources lead companies to different results, without these differences there is no competitive advantage; b) ex-ante competition limits: the financial return that an asset brings to the company has to be advantageous compared to the acquisition value; c) limits for ex-post competition: there must be exclusivity of valuable assets so that competitors cannot achieve the results achieved through these resources; $d$ ) imperfect mobility: the value of these assets is associated with the creation and combination of resources versus identity of the specific organization, which can result in other firms results quite different.

Barney (1991) put the resources in the VRIS model (valuable, rare, inimitable and non-replaceable) and in 2007 he perfected his ideas with the VRIO model (valuable, rare, inimitable and organizable). This change occurred by the perception that the inimitable characteristic was confused with the non-replaceable, one was inserted in the other. The 2007 model is the practical application of the theory (GONÇALVES et al, 2014).

Researches such as Beuren and Marcello (2016) reinforce that VRIO resources are essential elements of the strategy. Gonçalves, Coelho and Souza (2014) presented a theoretical discussion between RBV evolution with Barney (1991) and Resource Based Theory (RBT) with Barney and Clark (2007). Table 1 systematizes a comparison of Barney's works.

Table 1: Comparison between VRIS and VRIO

\begin{tabular}{|l|l|l|}
\hline $\begin{array}{l}\text { Characteristics of } \\
\text { resource }\end{array}$ & \multicolumn{1}{|c|}{$\begin{array}{c}\text { BARNEY, 1991 } \\
\text { VRIS }\end{array}$} & $\begin{array}{l}\text { BARNEY; CLARK, 2007 } \\
\text { VRIO }\end{array}$ \\
\hline FOCUS & $\begin{array}{l}\text { In the source strategy of a } \\
\text { value resource }\end{array}$ & $\begin{array}{l}\text { In the resource itself and in the ability to } \\
\text { allow external effects to be exploited or } \\
\text { neutralized }\end{array}$ \\
\hline VALUE & $\begin{array}{l}\text { They are the resources that } \\
\text { enable the company to adopt } \\
\text { a strategy that improves its } \\
\text { efficiency and effectiveness. }\end{array}$ & $\begin{array}{l}\text { It is the resources and capabilities that } \\
\text { enable the company to seize opportunities } \\
\text { or neutralize external threats. }\end{array}$ \\
\hline RARE & $\begin{array}{l}\text { If the resource has value and } \\
\text { many companies own it is not } \\
\text { a source of competitive } \\
\text { advantage }\end{array}$ & $\begin{array}{l}\text { If the resource or capacity is controlled by } \\
\text { many companies in the same industry, it } \\
\text { is rarely a source of competitive } \\
\text { advantage. }\end{array}$ \\
\hline INIMITABLE & $\begin{array}{l}\text { Valuable and rare resource is } \\
\text { only a source of competitive }\end{array}$ & $\begin{array}{l}\text { Valuable and rare resources are only a } \\
\text { source of sustainable competitive } \\
\text { advantage if the cost to obtain or develop }\end{array}$ \\
\hline
\end{tabular}


INDEPENDENT JOURNAL OF MANAGEMENT \& PRODUCTION (IJM\&P)

http://www.ijmp.jor.br

v. 10, n. 6, November - December 2019

ISSN: 2236-269X

DOI: 10.14807/ijmp.v10i6.1008

\begin{tabular}{|l|l|l|}
\hline SUBSTITUTABILITY & $\begin{array}{l}\text { advantage if imitation is not } \\
\text { possible. }\end{array}$ & $\begin{array}{l}\text { is too high to make it difficult for } \\
\text { competitors to have such a resource. }\end{array}$ \\
\hline $\begin{array}{l}\text { imitate the resource of a } \\
\text { company, it is possible to } \\
\text { replace it with another }\end{array}$ & $\begin{array}{l}\text { In VRIO was considered as a member of } \\
\text { INIMITABLE }\end{array}$ \\
\hline ORGANIZABLE & Not considered in VRIS & $\begin{array}{l}\text { In addition to possessing valuable } \\
\text { resources and capabilities, rare, without } \\
\text { limitation, the company organized. }\end{array}$ \\
\hline
\end{tabular}

Source: Adapted from Gonçalves, Coelho and Souza (2014).

In order to achieve a competitive advantage for a long time, the resources must present the characteristics VRIO together, when it is valuable and not uncommon, there is no competitive advantage, since it is similar to other companies; if a resource is valuable, rare, but it is easy to imitate, that company may have temporary competitive advantage; is the difficulty of imitation, whether by high cost or secret formula of doing something, which establishes sustainable competitive advantage (ALVARES, 2004).

For the VRIO model, having valuable, rare and inimitable / irreplaceable resources is not enough to obtain sustainable competitive advantage, it is necessary the organization attribute to exploit the resources to their full potential (GONÇALVES et al., 2014). These authors compared Barney's works, presented in 1991 and 2007, and perceived a repetition in the concepts of inimitability and substitutability. They agreed with Barney's (2007) understanding of the impossibility of substitution being embedded in inimitability. The VRIO resources of the companies must be known by their managers and investors. Disseminating information about these features can be a way to make the company more attractive and demonstrate transparency.

\subsection{Disclosure of Information}

The Theory of Disclosure has been approached by the international positivist research in accounting since the mid-1980s, by several authors, among them Verrecchia (1983) and Dye (1985), with the main purpose of explaining the disclosure of financial information, the effect of disclosure of financial statements on the price of shares and economically justify the choice of voluntary information (SALOTTI; YAMAMOTO, 2005). This theory presents two understandings: for Verrecchia (2001), there is no basic theory to deepen these studies beyond what has already been done and, for Dye (2001), this subject has a good theoretical basis (FORT et al., 2016).

The disclosure of accounting information is of fundamental importance in capital market activities (KOS; ESPEJO; RAIFUR, 2014), as they depict the whole 
INDEPENDENT JOURNAL OF MANAGEMENT \& PRODUCTION (IJM\&P)

http://Www.ijmp.jor.br

v. 10, n. 6, November-December 2019

ISSN: 2236-269X

DOI: 10.14807/ijmp.v10i6.1008

history of the organizations. Information has value only if it says something that is not yet known, considering a historical series of asset prices irrelevant (ROCHA; PROCIANOY, 2010).

Disclosing information to the market in greater quantity and better quality is usually understood as a way of equating information among shareholders and increasing the credibility of managers and managers in the capital market (AVELINO et al., 2014). The contributions of Trombeta (2002) warn that companies hardly divulge their information completely, voluntarily only reveal what they favor, thus there are three levels of disclosure, this decision is made according to the company's choice of strategy contained in the Table 2.

Table 2: Advantages and Disadvantages of Disclosure

\begin{tabular}{|l|l|l|}
\hline \multicolumn{1}{|c|}{ Type } & \multicolumn{1}{|c|}{ Advantages } & \multicolumn{1}{c|}{ Disadvantages } \\
\hline $\begin{array}{l}\text { Total } \\
\text { Disclosure }\end{array}$ & $\begin{array}{l}\text { - Maximum Transparency; - Good } \\
\text { Investor Relations - Low Cost of } \\
\text { Capital. }\end{array}$ & $\begin{array}{l}\text { - Information overload. - Loss of Competitive } \\
\text { Advantage. }\end{array}$ \\
\hline $\begin{array}{l}\text { Partial } \\
\text { Disclosure }\end{array}$ & $\begin{array}{l}\text { - Selectivity of information; Difficult to } \\
\text { distinguish from full disclosure; - } \\
\text { Absence of Disclosure Costs }\end{array}$ & $\begin{array}{l}\text { - Possibility of a high cost of capital; - Possible } \\
\text { loss of competitive advantage. }\end{array}$ \\
\hline $\begin{array}{l}\text { Not } \\
\text { Disclosed }\end{array}$ & $\begin{array}{l}\text { - Competitive Advantage Protection; - } \\
\text { Hide the bad news. }\end{array}$ & $\begin{array}{l}\text { - High Cost of Capital; - Negative reputation on } \\
\text { the markets. - Possible reaction of the } \\
\text { regulators. }\end{array}$ \\
\hline
\end{tabular}

Source: Trombetta (2002, p.5)

The level of detail of the disclosed information should be associated with the value and performance of the company (FERNANDES; SILVA, 2016). Increasing the level of information disclosure in the market leads to a decrease in the information gap between managers and investors, shareholders and suppliers of capital (MAROSKI; OSTH, 2015). Compulsory disclosures ensure that companies publish sufficient information for investors to act safely while volunteers bring enough benefits for the company to have an interest in publishing spontaneous information (FORT et al., 2016).

Disclosure has three levels: adequate, fair and complete disclosure. Adequate disclosure provides the minimum volume for the demonstration not to be considered misleading, fair disclosure discloses ethics as a fair treatment priority for all readers, and in full disclosure, the company goes through the ways of maximizing market value for evidencing information beyond (AVELINO et al., 2014).

The companies have been improving the forms of communication in several formats of disclosures: Quarterly Reports; Annual Reports Printed and Electronic; web conferencing; Meetings with Analysts; Meetings via the Internet; Visit to the Facilities; 
Websites; Roadshows; Updated electronic contents, among others (DONÁ et al., 2015). Fernandes and Silva (2016) cite as examples of accounting narratives the Management Reports, the Explanatory Notes and the Reference Forms.

Disclosure is the opening of the company through disclosure of information, provides corporate transparency to those interested and reduces the risk of irregularities and fraud (MAROSKI; OSTH, 2015), is one of the most efficient forms of communication between the organization and its stakeholders. The disclosure of information must be of good quality, timely and consistent; after all it is a proof of respect for shareholders and an asset in the credibility of the capital market (KOS; ESPEJO; RAIFUR, 2014).

When studying disclosure, it was observed that the act of disclosing information brings many advantages to the company, such as reduction of agency costs and cost of capital, greater ease in the sale of shares, among other less visible benefits, for this reason this practice has aroused the interest of scholars in deepening research on this subject (AVELINO et al., 2014).

\subsection{Organizational Performance}

The line of thought that considers competitive advantage is based on resources and observes the relationship between internal characteristics of an organization and its performance (BARNEY, 1991). Any valuable resource that provides conditions for the company to perform business operations efficiently and cost-effectively is a competitive advantage (CRUBELLATE; PASCUCCI; GRAVE, 2005).

Ribeiro, Scherer and Babosa da Silva (2016) state that, in situations where performance is obtained by the use of resources or capabilities that competitors do not have, the financial return is greater than that of competitors.

Medeiros and Mol (2016) investigated whether the persistence of superior performance in Brazilian companies listed in B3 by sector is related to tangibility, intangibility, levels of corporate governance and degree of social responsibility. Significant evidence has been found that intangibility imposes reductions on the persistence of the development of these firms in most industries.

Tangibility and corporate governance affect persistent performance in different ways. And the degree of social responsibility interferes, in a positive and significant way, in the insistence of the superior performance of the companies studied 
DOI: 10.14807/ijmp.v10i6.1008

(MATARAZZO, 1998; ASSAF NETO, 2002; MARION, 2005; KOS; ESPEJO; RAIFUR, 2014).

The economic and financial indicators are the basis for the performance appraisal, portraying the balance or financial, patrimonial and economic imbalance of organizations), among other authors consider the most cited indicators: Liquidity, Capital Structure and Profitability. Performance is how you measure the achievement of the organization's goals. The most applied profitability indicators are: Profitability on Shareholders' Equity, Profitability on Assets, Operating Margin; EBITDA, Earnings per share, Earnings per share, Net Asset Value per Share and Distributed Results (dividends) per share (KOS; ESPEJO; RAIFUR, 2014).

Traditional performance measures such as net income return on assets and budget variations do not provide information on future performance, intellectual capacities, or resources used by companies in their economic activities (BEUREN; MARCELLO, 2016). The company that performs well has greater liquidity, higher profitability and lower indebtedness (KOS; ESPEJO; RAIFUR, 2014).

Both the RBV and the Disclosure Theory are important approaches for the performance of companies that disclose their information, since VRIO resources have the potential to promote superior and sustainable performance, and the strategic disclosure of information influences the price of assets and, consequently, performance of the organization.

\section{METHODOLOGICAL ASPECTS}

This study is guided by the Resource Based View (RBV) and the Dissemination Theory discussed by Verrecchia (1983) and Dye (1985), whose design configures a qualitative research with detailed analysis. In agreement with the typologies of research designs cited by Raupp and Beuren (2006), the objectives of this study fit into a descriptive research, when reporting the influence between the disclosure of strategic resources and the performance in companies of the chosen sample.

In order to carry out the descriptive research it is necessary for the researcher to have information in sequence of what he intends to research, as an aid in describing the events of a given reality (GERHARDT; SILVEIRA, 2009). 
INDEPENDENT JOURNAL OF MANAGEMENT \& PRODUCTION (IJM\&P)

http://Www.ijmp.jor.br

v. 10, n. 6, November-December 2019

ISSN: 2236-269X

DOI: 10.14807/ijmp.v10i6.1008

Data from secondary sources were searched in the Economática database and in documentary analysis of information disclosed in company documents that aim to attract investors, such as the Reference Form.

Another aspect of this research was a detailed analysis of the companies' reference forms. In order to achieve the proposed objectives, this choice is the most coherent and adequate to verify the number of disclosure of the strategic resources based on the RBV.

Performance analysis was performed using the ROE, an index that measures profitability over equity and allows the evaluation of companies that present superior performance. For the calculation of the annual average and the standard deviation of the ROE of these companies some exclusions were made: companies that presented incomplete data, such as Miranda, Vasconcelos, Silva-Filho, Dos Santos and Maia (2013); Perez and Famá (2015); with negative PL for judging as financial solvency problems, such as Lara and Mesquita (2008); companies in the finance and insurance sector, since they have a very peculiar financial structure, according to Carvalho, Kayo and Martin (2010). There were 165 companies in 18 sectors. The highest annual averages of ROE were 24.34 in 2010 and 23.20 in 2011, as shown in table 1.

Table 1: Calculation of arithmetic mean and standard deviation

\begin{tabular}{|c|c|c|c|c|c|c|c|c|c|}
\hline Data & $\mathbf{2 0 1 0}$ & $\mathbf{2 0 1 1}$ & $\mathbf{2 0 1 2}$ & $\mathbf{2 0 1 3}$ & $\mathbf{2 0 1 4}$ & $\mathbf{2 0 1 5}$ & $\mathbf{2 0 1 6}$ & $\mathbf{2 0 1 7}$ & $\mathbf{2 0 1 8}$ \\
\hline Mean & 24,34 & 23,20 & 22,19 & 21,17 & 20,78 & 16,83 & 19,25 & 23,41 & 22,30 \\
\hline Standard Deviation & 26,19 & 21,57 & 20,89 & 20,49 & 22,74 & 21,38 & 20,58 & 22,01 & 19,75 \\
\hline
\end{tabular}

Source: Prepared by the authors based on data from Economática

Then, the arithmetic mean and standard deviation of ROE for each sector were calculated in the most profitable years, 2010 and 2011. Because of this calculation, four sectors with the highest index were highlighted in descending order: software and data, electronics, transport and services, and non-metal minerals; in 2011, software and data, transportation and services, commerce and electricity. Only two sectors are present in the two years: software and data, and transportation and services.

The first sector, besides presenting the highest standard deviation (according to information in table 2), is composed of only 2 companies, which makes its selection impossible to compose the sample of this research. Therefore, we selected the transport and services sector, whose sample is composed of 20 publicly traded companies of B3, according to table 2 . 
INDEPENDENT JOURNAL OF MANAGEMENT \& PRODUCTION (IJM\&P)

http://Www.ijmp.jor.br

v. 10, n. 6, November-December 2019

ISSN: 2236-269X

DOI: 10.14807/ijmp.v10i6.1008

Table 2: Arithmetic mean and standard deviation of ROE

\begin{tabular}{|c|c|c|c|c|c|}
\hline Sector & Number & $\mathbf{2 0 1 0}$ & $\mathbf{2 0 1 1}$ & $\mathbf{2 0 1 0}$ & $\mathbf{2 0 1 1}$ \\
\hline Agro and fishing & 1 & 3,10 & 8,30 & - & - \\
\hline Food and drinks & 7 & 11,89 & 16,37 & 10,03 & 11,93 \\
\hline Trade & 10 & 27,70 & 35,96 & 20,55 & 38,71 \\
\hline Constrution & 10 & 28,34 & 19,24 & 20,50 & 6,67 \\
\hline Appliance & 2 & 36,35 & 20,75 & 1,06 & 0,35 \\
\hline Electricity & 38 & 30,93 & 26,42 & 41,85 & 17,65 \\
\hline Industrial machines & 1 & 15,10 & 15,50 & - & - \\
\hline Non-metal ores & 3 & 27,80 & 20,03 & 23,90 & 11,01 \\
\hline Others & 41 & 14,28 & 15,62 & 8,64 & 15,73 \\
\hline Paper And Cellulose & 1 & 7,40 & 2,00 & - & - \\
\hline Oil and Gas & 4 & 21,88 & 15,90 & 17,42 & 10,60 \\
\hline Chemistry & 2 & 11,45 & 8,25 & 4,74 & 9,97 \\
\hline Siderurgical and metallurgical & 6 & 10,92 & 9,20 & 4,04 & 4,23 \\
\hline Software and data & 2 & 87,55 & 75,05 & 92,98 & 74,18 \\
\hline Telecommunications & 3 & 23,37 & 14,97 & 4,04 & 8,60 \\
\hline Textile & 6 & 24,38 & 20,95 & 15,30 & 11,87 \\
\hline Transport and services & 20 & 34,42 & 40,16 & 12,83 & 26,48 \\
\hline Vehicles and spare parts & 8 & 21,78 & 16,35 & 15,02 & 8,12 \\
\hline
\end{tabular}

Source: Prepared by the authors based on data from Economática

The main reason for the choice of the sample by companies that compose B3 was the same one cited by Bueno (1999) when considering them more transparent, since the data are audited and exposed to the market, therefore, they provide security and credibility.

For the selection of the sample, we searched for financial information provided by the Economática database for an analysis of the superior performance of the companies that published information in B3. The period analyzed for the sample was from 2010 to 2018 , starting on that date as the first year after the regulation of the Reference Form by ICVM n. 480/2009.

Table 3: ROE of the companies of the sector transport and services

\begin{tabular}{|c|c|c|}
\hline Companies / year & $\mathbf{2 0 1 0}$ & $\mathbf{2 0 1 1}$ \\
\hline AG concessões & 37,60 & 17,10 \\
\hline All Norte & 44,10 & 30,80 \\
\hline Arteris & 28,00 & 28,90 \\
\hline Autoban-Conc. do Sist. Anhanguera Bandeirantes S/A & 47,30 & 110,30 \\
\hline Autovias AS & 37,20 & 36,80 \\
\hline CCR AS & 21,60 & 28,30 \\
\hline Centrovias Sistemas Rodov. S/A & 55,40 & 51,40 \\
\hline Conc. de Rod. do Oeste de SP - Viaoeste S/A & 36,00 & 47,70 \\
\hline Conc. de Rodov. do Interior Paulista S/A & 43,00 & 48,30 \\
\hline Conc. Rio Ter & 42,80 & 49,40 \\
\hline Conc. Rodov. Pres. Dutra S/A & 37,30 & 45,60 \\
\hline Conc. Ecovias Dos Imigrantes S/A & 45,90 & 65,20 \\
\hline Ecorodovias & 33,20 & 20,60 \\
\hline Ecorodovias Concessões e Serv. S/A & 49,90 & 43,40 \\
\hline JSL & 11,40 & 6,70 \\
\hline Menezes Cort & 11,90 & 13,10 \\
\hline Mrs Logist & 21,90 & 22,70 \\
\hline
\end{tabular}


INDEPENDENT JOURNAL OF MANAGEMENT \& PRODUCTION (IJM\&P)

http://Www.ijmp.jor.br

v. 10, n. 6, November-December 2019

ISSN: 2236-269X

DOI: 10.14807/ijmp.v10i6.1008

\begin{tabular}{|c|c|c|} 
& \multicolumn{1}{|c|}{43,00} & 96,40 \\
\hline Rodonorte- Conc. Rod. Integradas S/A & 17,60 & 20,50 \\
\hline Vianorte S/A & 23,20 & 19,90 \\
\hline
\end{tabular}

Source: Elaborated by the authors from the Economática data.

In the classification of B3, the sector selected for the sample is inserted in the economic sector of material goods, transportation subsector. It is subdivided into the segments of Air, Rail, Waterway, Highway, Highway Exploration and Support and Storage Services. Some of the information regarding the disclosure of funds was extracted from the B3 website, accessed through the 'fast access', 'listed companies', 'sector of activity' option, access to companies in the transportation and services sector, 'financial reports' and low the 'Reference Forms'. Three sectors were excluded from the sample because they presented only one company: agriculture and fishing, industrial machinery, and paper and pulp.

In cases where the data were not found or were incomplete, other sources of information such as the CVM website were used in 'company', periodical and occasional information of companies', by name or CNPJ, and downloaded the report for the survey or the company's own website at: 'investor relations' and choose the document for the survey.

\section{PRESENTATION AND DISCUSSION OF RESULTS}

Based on the RBV line of thought, a theoretical framework was elaborated formed by four categories that classify the resources cited in this research: physical, financial, human and organizational. The definition of the categories was based on the resources included in the RBV approach to be introduced in the IT Atlas, in codes, and grouped into families according to common characteristics. As financial resources there are shareholders, creditors and money (PADILHA; BANDEIRA-DE-MELLO, 2007), financing capacity and revenues (BARCELOS et al, 2011).

For the latter authors financial resources are the pillar to obtain the other resources. Physical resources are "assets that make it possible to implement strategies to improve the efficiency of organizational processes" (BARNEY, 1991). Human resources correspond to the capabilities of the company, because they integrate the experience, judgment, intelligence, relationships and the individual vision of the managers with the opportunities available in the market and the organizational resources are a union of the people of the organization with the formal structure of corporate reporting, formal and informal planning systems (BARNEY, 2002). 
In order to assist this step, the systematic procedures for data analysis and coding were used, software was used to organize, separate and visualize the selected strategic information. Atlas IT software is identified as a support tool for the analysis of qualitative data fed by the computer. Its development was given by the Technical University of Berlin to attend a multidisciplinary project (1989-1992), whose objective was to interpret texts in the late 80's. Atlas comes from the German Archiv fuer Technik, Lebens weltund Alltagassprache, translated as archive for technology, the world and everyday language. TI, is translated as text interpretation (BANDEIRA-DEMELLO, 2006).

Bandeira-de-Mello (2006) highlights the most important components of the program: a) hermeneutical unit: union of all data and elements; b) primary documents: are the primary data collected; c) citations: data segments, such as relevant excerpts from the primary document; d) codes: they are concepts or categories generated by the interpretations of the researcher; e) memos or notes of analysis: describe the history of the research and record the interpretations of the researcher; f) graphical schemes: they are graphical representations of the associations between codes. In selecting each of these terms in the Reference Forms, an in-depth analysis of each specific expression and interpreted within the context according to the criteria of the RBV theory was made, in a set of concepts and categories of the theory in search of evidence of resources in the documents of the organizations under study.

Detailed analysis was used as a search technique. In order to facilitate this process, the research design was based on the theoretical framework derived from RBV, which brought together the main resources and capacities, central objects of this research, according to Table 4. According to the data observed in the realization of documentary research, the resources presented in the greatest number of each category are: physical resources: technology and equipment; of financial resources: shareholder and money; human resources: expertise, knowledge and staff; and organizational resources: brand and governance. After the detailed analysis of the strategic resources in the Reference Forms, table 4 presents the number of disclosures in 2010 and 2011. 
INDEPENDENT JOURNAL OF MANAGEMENT \& PRODUCTION (IJM\&P)

http://Www.ijmp.jor.br

v. 10, n. 6, November-December 2019

ISSN: 2236-269X

DOI: 10.14807/ijmp.v10i6.1008

Table 4: Theoretical Framework and dissemination of strategic resources

\begin{tabular}{|c|c|c|c|c|}
\hline Categories & Theoretical basis & Resources / capabilities & 2010 & 2011 \\
\hline \multirow{6}{*}{ Physical } & Carvalho, Prevot e Machado (2012) & Equipments & 7 & 4 \\
\hline & Padilha e Bandeira-de-Mello (2007) & Geographic location & 4 & 2 \\
\hline & Penrose (1959); & Machines & 3 & 2 \\
\hline & Bandeira-de-Mello et. al. (2011) & Plant & 3 & 3 \\
\hline & Carvalho, Prevot e Machado (2012) & Technology & 11 & 4 \\
\hline & Padilha e Bandeira-de-Mello (2007) & Physical and technology & 0 & 3 \\
\hline \multirow{5}{*}{ Financial } & Padilha e Bandeira-de-Mello (2007) & Shareholders & 1 & 1 \\
\hline & Bandeira-de-Mello et. al. (2011) & Financing capacity & 0 & 0 \\
\hline & Padilha e Bandeira-de-Mello (2007) & Creditors & 0 & 0 \\
\hline & Padilha e Bandeira-de-Mello (2007) & Money & 1 & 1 \\
\hline & Bandeira-de-Mello et. al. (2011) & Revenues & 0 & 0 \\
\hline \multirow{8}{*}{ Human } & Barney (1991); & Knowledge & 3 & 2 \\
\hline & Penrose (1959) & Hiring of specialized people & 1 & 1 \\
\hline & Carvalho, Prevot e Machado (2012) & Development of competences & 2 & 0 \\
\hline & Bandeira-de-Mello et. al. (2011) & Technical and qualified team & 2 & 5 \\
\hline & Fonseca e Cunha (2015) & Expertise & 5 & 3 \\
\hline & Padilha e Bandeira-de-Mello (2007) & Offices & 0 & 0 \\
\hline & Padilha e Bandeira-de-Mello (2007) & Relationships & 1 & 0 \\
\hline & Carvalho, Prevot e Machado (2012) & Trainings & 1 & 1 \\
\hline \multirow{14}{*}{ Organizational } & Barney (1991) & Management control & 1 & 0 \\
\hline & Padilha e Bandeira-de-Mello (2007) & Coordination & 0 & 2 \\
\hline & Barney e Clark (2007); & Organizational culture & 0 & 0 \\
\hline & Henri (2006) & Business & 0 & 0 \\
\hline & Bandeira-de-Mello et. al. (2011) & Corporate governance & 3 & 3 \\
\hline & Carvalho, Prevot e Machado (2012) & Innovation & 2 & 1 \\
\hline & Penrose (1959); Collin (2005); & Brand & 11 & 12 \\
\hline & Vasconcelos e Brito (2004) & Marketing & 1 & 1 \\
\hline & Collin (2005); Ferraresi et al. (2012) & Patents & 0 & 0 \\
\hline & Padilha e Bandeira-de-Melllo (2007) & Planning & 1 & 3 \\
\hline & Collin (2005) & Procedures & 0 & 1 \\
\hline & Grant (1991); & Reputation & 0 & 0 \\
\hline & Collin (2005); & Routines & 0 & 0 \\
\hline & Barney e Clark (2007) & Values & 1 & 1 \\
\hline
\end{tabular}

Source: Elaborated by the authors with research data

The use of this tool softens the researcher's burden to interpret and understand his research (BANDEIRA-DE-MELLO, 2006). Barcelos, Marcon and Bandeira-de-Mello (2011) emphasize that the program is prepared to simplify the organization of information and to create codes and families, but it is necessary to understand how these connectors work and communicate, so that there are insights in understanding the data.

The findings of this research are in line with the findings of Miranda et al. (2013) regarding investments in intangible assets, which are positively related to the market value of the companies surveyed, but are not related to ROE. A company that 
INDEPENDENT JOURNAL OF MANAGEMENT \& PRODUCTION (IJM\&P)

http://Www.ijmp.jor.br

v. 10, n. 6, November-December 2019

ISSN: 2236-269X

DOI: 10.14807/ijmp.v10i6.1008

has high ROE and low disclosure can be considered a form of protection, since full disclosure entails loss of competitive advantage (TROMBETA, 2002).

The most publicized features over the two years are technology and brand. The results of this research disagree with the study by Carvalho et. al. (2012), since they affirm that the strategic technological resources of the rural sector are the least cited by the company. For the authors, this variation is due to the particularity of each sector in relation to innovation and technological impacts. Norton's (2001) observations explain this fact by pointing out that intangible assets, such as technology, are unlikely to be directly related to revenue or profit, the effects of which are indirect.

The brand is widely publicized, because companies do not care enough to protect it because of the difficulty in copying this type of resource. This perception is in line with the conclusions of Hexsel and Lagreca (2007), accumulation of resources is directly associated with the brand because they are difficult to reproduce by other companies and consider it an important resource, the result of continuous and specific investments in the long term.

The results of this research corroborate the rationale of the Theory of Disclosure, when Verrechia (2001) associates the decision to disclose to the judgment of the manager, discloses what is interesting to the organization. The results also meet Dye's (2001) understanding of the information disclosure inserted in the Game Theory, since managers' decisions seek the cost-benefit relation of the disclosed information, but the benefit must always exceed cost. For the latter author, disclosing only what favors the company protects it from competitors, as evidencing strategic resources would facilitate modeling by these competitors, although it favors investors. There are several other ways to arouse the investor's interest, as well as to divulge the source of competitive advantage.

The most publicized Strategic Physical Resources were, respectively, technology and equipment in 2010, and equipment and technology in 2011. The companies that most publicized these resources were Ecorodovia Concessionária, with 4 disclosures in 2010, and Ecorodovia, with 5 disclosures in 2011. In 2010, any company did not disclose hardware and software as strategic, in 2011 all the resources listed in table 6 had at least two disclosures.

The most publicized strategic financial resources in 2010 and 2011 were shareholder and cash, each with a single disclosure. It is important to note that the 
DOI: 10.14807/ijmp.v10i6.1008

only company that disclosed these resources as strategic was Ecorodovia. Lenders, financing capacity and billing were not disclosed as strategic by any company. In the literature there are data that coincide with this result, such as those of Carvalho, Prevot and Machado (2012), when they affirm that strategic financial resources were the least cited. Hendriksen and Van Breda (1999) justify this resistance of organizations to increase the degree of disclosure to hinder the possibility of information being used by their competitors.

Figure 1 illustrated below shows the most publicized strategic organizational resources in 2010 and 2011. Brand and corporate governance are ahead in the two years. Noteworthy are the companies that most publicized the category of organizational resources in 2010: Ecorodovia and JSL with 4 disclosures each, and in 2011, JSL with 5 disclosures. Organizational resources such as coordination, organizational culture, reputation, routine, entrepreneurship and patents were not disclosed as strategic in 2010 and 2011. Also noteworthy is an effective procedure as an undisclosed resource in 2010.

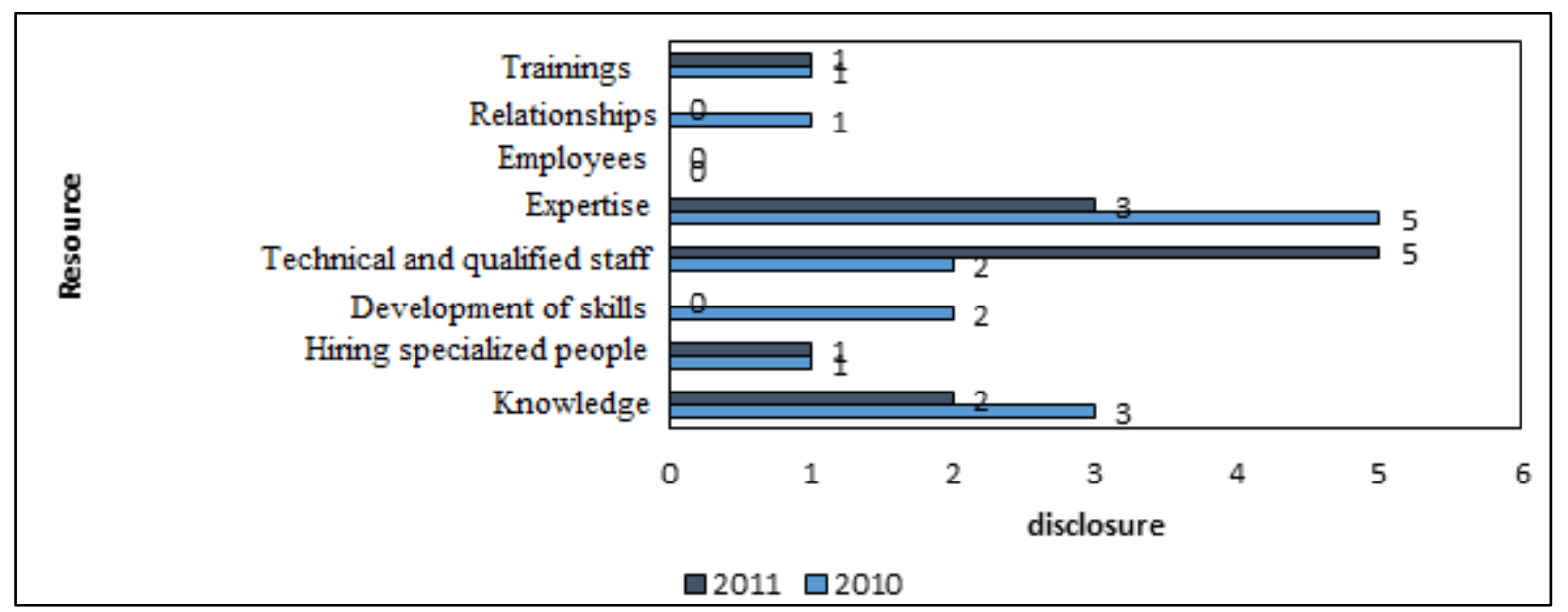

Figure 1: Strategic Human Resources Disclosure Chart

Source: Prepared by the authors

The most publicized strategic human resources were, in 2010, expertise and knowledge and in 2011, team and expertise. They stand out as the companies that most publicized this type of resource in 2010, Vix and in 2011 the Ecorodovia, each with 5 disclosures. We have as undisclosed resources as strategic: employees in 2010, and development of skills, employees and relationships in 2011. These results are in line with the findings of Souza et al. (2016) when they concluded that disclosure of human resources is low. 
DOI: 10.14807/ijmp.v10i6.1008

This result is justified by Carvalho, Kayo and Martin (2010), when they understand brand as an intangible asset that contributes to the creation of value of firms, because it is responsible for the choice of consumers and the image associated with the product or service. A strong brand creates a link between product/service and the customer, greater loyalty to competitive marketing, and more attractive profit margins. Therefore, good governance practices protect the interests of shareholders through procedures adopted by managers and favor strategic management of the company and follow-up of executive management planning and actions (CATAPAN; DOUGLAS, 2013). These authors reinforce the importance of disseminating this resource as strategic.

\section{FINAL CONSIDERATIONS}

The main objective of this study was to analyze the relationship between the disclosure of strategic organizational resources and the performance of companies listed in B3, in the most profitable sector of 2010 and 2018, transportation and services. In order to achieve this objective, the following variables were considered: resources considered strategic in RBV theory and ROE to measure performance in the Economática database. Resources were classified into four categories: physical, financial, human, and organizational.

When analyzing the resources most divulged by categories they are verified: the physical resources, technology and equipment; financial resources, shareholders and money; human resources, expertise, knowledge and staff; and organizational resources, branding and corporate governance. It was observed that the category of organizational resources was the most publicized category and the least publicized financial category. In general, the resources that reached the highest number of disclosure were technology (physical resources) and brand (organizational resources).

We used the RBV theory and the Disclosure Theory to try to explain the findings of the research. It is concluded that the disclosure of strategic resources is not related to the superior performance of the company, therefore, it is not a source of competitive advantage. A significant number of companies with high ROE disclose few or none of these resources, this behavior may be associated with the protection of strategic information from the company to competitors. The majority of companies that chose not to disclose strategic resources had above-average ROE and the companies 
INDEPENDENT JOURNAL OF MANAGEMENT \& PRODUCTION (IJM\&P)

http://Www.ijmp.jor.br

v. 10, n. 6, November - December 2019

ISSN: 2236-269X

DOI: 10.14807/ijmp.v10i6.1008

with the highest number of disclosures obtained ROE below average, and there was also a variability between the number of disclosures and ROE.

Companies only disclose information that, to a certain extent, offers them advantages. Disclosing its strategic resources can bring more disadvantage than advantage, after all, it is easier for competitors to try to copy the strategy through these resources and the company can lose the competitive advantage.

This result is in line with the theory of disclosure regarding the strategic disclosure of resources. The choice of these strategic resources to be disclosed deserves close scrutiny with the objective of protecting them, since they collaborate to achieve the competitive advantage. Given these results, it is possible to conclude that the objectives of the work have been achieved. The present study sought to fill the theoretical gaps, to contribute to the evolution of the researches in strategy and to relate the RBV with another theory, in this case the theory of the disclosure. It also sought to contribute to the business practice in choosing the information to be disclosed.

Four limitations were experienced. The first, the contradiction and imperfect overlap between the concepts of resources and capacity building, flexibility is important for discoveries and evolutions of the definitions of concepts, but they hinder a global and logical understanding. The second, although organizational performance is the most studied and used construct in the field of strategy, its approach is incomplete. Because it is a complex and multidirectional construct, it presents innumerable dimensions and an immense variety of approaches, besides the complexity in defining or explaining organizational performance.

\section{REFERENCES}

ALVARES, A. C. T. (2004) Incentive to the generation of ideas: internal system of suggestions of high performance. RAE-Revista de Administração de Empresas, v. 55, n. 3, p. 368-369.

ARAGÃO, L. A.; CAVALCANTE, D. S. (2014) Quality of the information of the reference forms of the Brazilian companies listed in the new BM \& FBovespa market. RACE, v. 13, n. 3, p. 1089-1118, set./dez.

ARANHA, C. E.; ROSSONI, L.; MENDES-DA-SILVA, W. (2016) Social Capital Of The Board Of Directors And Performance Of Brazilian Public Companies. RAM, v. 17, n. 1, p. 15-39.

ARAÚJO, U. P.; JOSÉ DE BRITO, M.; RIBEIRO, L. M. P.; LOPES, F. T. (2016) Meter: Fifteen Years of Research with the Management Report. Revista

Contabilidade \& Finanças, v. 27, n. 71, p. 217-231. 
ARAÚJO, V. R. B. S. (2016) Corporate disclosure and share liquidity: an analysis of different size levels of Brazilian companies. Dissertation (MSc in Accounting Sciences) - University of Brasília, Federal University of Paraíba and Federal University of Rio Grande do Norte, João Pessoa-PB.

ASSAF, N. A. (2002) Structure of balance sheets: an economic-financial approach, trade and services, industries, commercial and multiple banks. São Paulo, Atlas.

AVELINO, B. C.; DA CUNHA, J. V. A.; DE LIMA, G. A. S. F.; COLAUTO, R. D. (2014) Explanatory characteristics of the level of voluntary disclosure of municipalities in the state of Minas Gerais. Race: journal of management, accounting and economics, v. 13, n. 2, p. 571-608, 2014.

BANDEIRA-DE-MELLO, R. (2006). Software in qualitative research. Qualitative research in organizational studies: paradigms, strategies and methods. São Paulo, SP: Saraiva.

BARCELOS, L.; MARCON, R.; BANDEIRA-DE-MELLO, R. (2011) Evidence of organizational resources and capabilities: a case study in light of RBV theory. Journal of Business, v. 16, n. 3, p. 113-134.

BARNEY, J. B. (1986) Strategic factor markets: Expectations, luck, and business strategy. Management science, v. 32, n. 10, p. 1231-1241.

BARNEY, J. B. (1991) Firm resource and sustained competitive advantage. Journal of Manegement.

BARNEY, J. B. (1995) Looking inside for competitive advantage. The Academy of Management Executive, v. 9, n. 4, p. 49-61.

BARNEY, J. B. (2001) Is the Resource-Based "View" a Useful Perspective for Strategic Management Research? Yes. Academy of Management Review, v. 26, n. 1, p. 41-56.

BARNEY, J. B. (2002) Strategic management: From informed conversation to academic discipline. The Academy of Management Executive, v. 16, n. 2, p. 5357.

BARNEY, J. B.; CLARK, D. N. (2007). Resource-based theory: Creating and sustaining competitive advantage. Oxford University Press on Demand.

BESANKO, D.; DRANOVE, D.; SHANLEY, M.; SCHAEFER, S. (2009) The economics of strategy. Bookman Editora.

BEUREN, I. M.; ANGONESE, R. (2015) Instruments for determining the disclosure index of accounting information. Revista Eletrônica de Estratégia \& Negócios, v. 8, n. 1, p. 120-144.

BEUREN, I. M.; MARCELLO, I. E. (2016) Relation of the Importance of the Strategic Resources with the Measures of Performance in Brazilian Companies. IJSM, v. 15, n. 1, p. 65-82.

BRITO, L.A. L.; VASCONCELOS, F. C. (2004) Firm performance in an extremely turbulent environment: year, industry and firm effects. Anais do EnANPAD.

BUENO, A. F. (1999) Problems of disclosure in Brazil: the case of companies with shares abroad. Book of Studies, n. 20, p. 01-13. 
INDEPENDENT JOURNAL OF MANAGEMENT \& PRODUCTION (IJM\&P)

http://Www.ijmp.jor.br

v. 10, n. 6, November-December 2019

ISSN: 2236-269X

DOI: 10.14807/ijmp.v10i6.1008

CARVALHO, D. M.; PREVOT, F.; MACHADO, J. A. D. (2012) The role of resources in organizational performance: the use of resource-based view theory in rural properties. ENANPAD, v. 36.

CATAPAN, A.; COLAUTO, R. D. (2014) Corporate governance: an analysis of its relation with the economic-financial performance of companies listed in Brazil in the years 2010-2012. Accounting and Administration, v. 59, n. 3, p. 137-164.

COLAUTO, R. D.; NASCIMENTO, P. S.; AVELINO, B. C.; BISPO, O. N. A. (2009) Evidence of intangible assets not acquired in the management reports of listed companies in the Bovespa corporate governance levels. Accounting Vista \& Revista, v. 20, n. 1, p. 143-169.

COLLIS, D. J.; MONTGOMERY, C. A. (1995) Competing on Resources: Strategy in the 1990s. Knowledge and strategy, p. 25-40.

CRUBELLATE, J. M.; PASCUCCI, L.; GRAVE, P. S. (2005) Vision based on legitimate resources: resources and institutional standards in the formulation of strategies in organizations. Meeting Studies In Strategy, v. 2.

BRAZIL, Brazilian Securities and Exchange Commission (CVM). (2017) CVM Resolution No. 488/05. Available at: <www.cpc.org.br>. Accessed on: 09 February 2017.

DA SILVA, J. F.; DA MOTTA, L. F. J. (2012) The competitive advantage of nations and the competitive advantage of companies: what matters in the localization. RAP, v. 46, n. 3 , p. $701-720$.

DE OLIVEIRA SILVA, M. F.; SILVA, J. F.; DA MOTTA, L. F. J. (2012) The Competitive Advantage of Nations and the Competitive Advantage of Firms: What Matters in Localization? Journal of Public Administration, v. 46, n. 3, p. 701-720.

DE OLIVEIRA, M. O. R.; SCHOSSLER, D. P.; CAMPOS, R. E.; LUCE, F. B. (2014) Intangible assets and economic-financial performance: comparison between tangible-intensive and intangible-intensive business portfolios. Journal of Management of UFSM, v. 7, n. 4, p. 678-699.

MOURA, G. D.; VARELA, P. S.; BEUREN, I. M. (2014) Conformity of Mandatory Disclosure of Intangible Assets and Corporate Governance Practices. Journal of Management Mackenzie, v. 15, n. 5.

DE SOUZA, C. M. L. (2011) Between Formal and Informal Strategic Planning: an Exploratory Case Study on the Strategy Practice in Organizations. RAC, v. 15, n. 5, p. 855.

DIERICKX, I.; COOL, K. (1989) Asset stock accumulation and sustainability of competitive advantage. Management Science, vol. 35, n. 12.

DONÁ, A. L.; MARQUES, K. C. M.; MORIBE, A. M.; HERCOS JUNIOR, J. B. (2015) Factors determining the content disclosed in the report of management of Brazilian companies. Journal of Mathematics, v. 11, n. 4, p. 82.

DYE, R. A. (1985) Disclosure of nonproprietary information. Journal of accounting research, p. 123-145.

DYE, R. A. (2001) An evaluation of "essays on disclosure" and the disclosure literature in accounting. Journal of Accounting and Economics, v. 32, n. 1, p. 181235. 
INDEPENDENT JOURNAL OF MANAGEMENT \& PRODUCTION (IJM\&P)

http://Www.ijmp.jor.br

v. 10, n. 6, November-December 2019

ISSN: 2236-269X

DOI: 10.14807/ijmp.v10i6.1008

ESPÍNDULA, R. P.; DE SOUZA COSTA, P. (2008) Analysis of the influence of the publication and readability of the relevant acts or facts on the share price of Brazilian publicly traded companies from 2002 to 2006. Horizonte, v. 2, n. 1.

FERNANDES, J. L. T.; SILVA, C. A. T. (2016) Performance analysis as a characteristic of Brazilian publicly traded companies in the disclosure of relevant facts in 2010. Registro Contábil, v. 6, n. 3, p. 22-37.

FERNANDES, B.H.R.; FLEURY, M. T. L.; MILLS, J. (2006) Building the dialogue between competence, resources and organizational performance. RAE, v. 46, n. 4.

FERRARESI, A. A.; QUANDT, C. O.; DOS SANTOS, S. A.; FREGA, J. R. (2012) Knowledge management and strategic orientation: lever aging in novativeness and performance. Journal of Knowledge Management, v. 16, n. 5, p. 688-701.

FORTE, L. M.; DOS SANTOS NETO, J. B.; NOBRE, F. C.; NOBRE, L. H. N.; QUEIROZ, D. B. (2016) Determinants of Voluntary Disclosure: A Study in the Brazilian Banking Sector. Journal of Management, Finance and Accounting, v. 5, n. 2, p. 23-37.

GONÇALVES, A. R.; QUINTELLA, R. H. (2005) Contribution of internal and external factors to the performance of Brazilian companies and their revolution in the last decade. In: Anais ENANPAD, 29, 2005, Brasília.

GONÇALVES, C. A.; DE FREITAS COELHO, M.; SOUZA, É. M. (2014) VRIO: Competitive advantage sustainable by the organization. Journal of Management Science, v. 17, n. 3.

GRANT, R. (1991) The resource-based theory of competitive advantage: Implications for strategy formulation. California Management Review, v. 33, n. 3, p. 114-135.

HELFAT, C. E.; PETERAF, M. A. (2003) The dynamic resource-based view: Capability lifecycles. Strategic management journal, v. 24, n. 10, p. 997-1010.

HENRI, J. F. (2006) Management control systems and strategy: a resource-based perspective. Accounting, Organizations and Society, n. 31, p. 529-558.

HOSKISSON, R.E.; HITT, M.A.; WAN, W. P.; YIU, D. (1999) Theory and research in strategic management: Swings of a pendulum. Journal of management, v. 25, n. 3, p. 417-456.

KOS, S.R.; MIRROR, M. M. S. B.; RAIFUR, L. (2014) The information content of the management report and the performance of Ibovespa's Brazilian companies.

Journal of Mathematics, v. 10, n. 2, p. 43-62.

MACHADO-DA-SILVA, C. L.; FONSECA, V. S.; FERNANDES, B. H. R. (1999) Change and strategy in organizations: cognitive and institutional perspectives. Contemporary management: strategic perspectives. São Paulo: Atlas.

MARITAN, C. A.; PETERAF, M. A. (2011) Invited editorial: Building a bridge between resource acquisition and resource accumulation. Journal of management, v. 37, n. 5, p. 1374-1389.

MATARAZZO, D. C. (1998) Financial analysis of balance sheets: a basic and managerial approach. São Paulo: Atlas. 
INDEPENDENT JOURNAL OF MANAGEMENT \& PRODUCTION (IJM\&P)

http://Www.ijmp.jor.br

v. 10, n. 6, November-December 2019

ISSN: 2236-269X

DOI: 10.14807/ijmp.v10i6.1008

MIA, L.; CLARKE, B. (1999) Market competition, management accounting systems and business unit performance. Management Accounting Research, v. 10, n. 2, p. 137-158.

MINTZBERG, H.; WATERS, J. A. (1985) Of strategies, deliberate and emergent. SMJ, v. 6, n. 3, p. 257-272.

MINTZBERG, H.; AHLSTRAND, B.; LAMPEL, J. (2000) Strategy Safari: A Jungle Roadmap of Planning. Translation Nivaldo Montingelli Jr.

MIRANDA, K. F.; VASCONCELOS, A. C.; SILVA-FILHO, J. C. L.M.; SANTOS, J. G. C.; MAIA, A. B. G. R. (2013) Intangible assets, degree of innovation and performance of Brazilian companies from innovative sectoral groups. RGO, v. 6, n. 1, p. 4.

MURCIA, F. D.; DOS SANTOS, A. (2009) Factors determining the level of voluntary disclosure of publicly traded companies in Brazil. REPeC, v. 3, n. 2, p. 72-95.

OYADOMARI, J. C. T.; FREZATTI, F.; BRAGA DE AGUIAR, A.; CARDOSO, R. (2009) Analysis of the works that used the Simons Levers of Control model in the international literature from 1995 to 2007 . RCO, v. 3, n. 7, p. 25-42.

PADILHA, E.; BANDEIRA-DE-MELLO, R. (2007) An analysis of the heterogeneity of small companies in the light of the Resource Based View (RBV): the case of the Professional Engineering Services. XXXI ANPAD NATIONAL MEETING.

PENROSE, E. T. (1959) The Theory of the Growth of the Firm. Oxford University Press.

PEREZ, M. M.; FAMÁ, R. (2006) Intangible assets and business performance.

Revista Contabilidade \& Finanças, v. 17, n. 40, p. 7-24.

PETERAF, M. A. (1993) The Cornerstones of Competitive Advantage: A ResourceBased View. Strategic Management Journal, v. 14, p. 179-191.

PETERAF, M. A.; BARNEY, J. B. (2003) Unraveling the resource-based tangle. Managerial and decision economics, v. 24, n. 4, p. 309-323.

PORTER, M. E. (1980) Industry structure and competitive strategy: Keys to profitability. Financial Analysts Journal, v. 36, n. 4, p. 30-41.

PORTER, M. E. (1990) The competitive advantage of nations. Harvard business review, v. 68, n. 2, p. 73-93.

PORTER, M. E. (1996) What is strategy? Published November.

PORTER, M. E. (1999) Competition: essential competitive strategies. Rio de Janeiro, Campus.

RAUPP, F. M.; BEUREN, I. M. (2006) Research Methodology Applicable to Science. São Paulo: Atlas.

RIBEIRO, F.; SCHERER, L. M.; DA SILVA, A. A. B. (2016) Resource Based View: a study of the impact of the financial crisis on the heterogeneity of the performance of Brazilian publicly traded companies. However, 14, n. 2, p. 09-24.

RIBEIRO, R.; ROSSETTO, C. R.; VERDINELLI, M. A. (2011) Strategic company behavior and resource-based view: a study in the retail sector of construction material. Management \& Production, v. 18, n. 1, p. 175-192. 
ROCHA, C.F. P.; PROCIANOY, J. L. (2010) Disclosure of Brazilian publicly traded companies: an exploratory study. Electronic Journal of Organizational Management, v. 2, n. 3.

SALAZAR, V. S. (2015) Acquisition and development of strategic resources of gastronomic restaurants: a multi-country study in Latin America. Thesis (Doctoral Degree in Administration, area of Organizational Management concentration) - Federal University of Pernambuco, Recife, PE.

SALOTTI, B. M.; YAMAMOTO, M. M. (2005) Essay on the theory of dissemination. BBR, v. 2, n. 1, p. 53-70.

SERRA, F. A.; RIBEIRO et al. (2017) Evolution of research in RBV: a study of the last EnANPAD's. REBRAE, v. 1, n. 1.

SOUZA, G. H. C.; FELIX JUNIOR, L. A.; LAGIOIA, U. C. T.; NASCIMENTO DE ARAÚJO, J. G. (2016) Financial performance and disclosure of human resources information: an analysis of IBRX-100 companies. REPeC, v. 10, n. 1.

TEECE, D. J.; PISANO, G.; SHUEN, A. (1997) Dynamic capabilities and strategic management. SMJ, v. 18, n. 7, p. 509-533, 08.

TROMBETTA, M. (2002) The decision to voluntarily disclose company information: from the theoretical analysis to a methodological proposal. Working Paper.

Department of Business Economics. University Carlos III. Madrid.

VASCONCELOS, F. C.; CYRINO, Á. B. (2000) Competitive Advantag: the current theoretical models e. RAE, v. 40, n. 4, p. 21.

VERRECCHIA, R. E. (2001) Essays on disclosure. Journal of Accounting and Economics, v. 32, n. 1, p. 97-180.

YAMAMOTO, M. M.; SALOTTI, B. M. (2005) Accounting information: studies on its disclosure in the capital market. São Paulo: Atlas. 